\section{Evaluation of Table Grape Storage in Boxes with Sulfur Dioxide-releasing Pads with Either an Internal Plastic Liner or External Wrap}

\author{
Ammon Lichter, Yohanan Zutahy, Tatiána Kaplunov, \\ and Susan Lurie ${ }^{1}$
}

\begin{abstract}
AdDitional INDEX wORDs. Vitis vinifera, decay, fruit quality, $\mathrm{SO}_{2}$, Botrytis cinerea
Summary. Two main methods are in use for packing table grapes (Vitis vinifera) for refrigerated storage and transport. One is to pack the grapes with a sulfur dioxide $\left(\mathrm{SO}_{2}\right)$ generator pad inside a box with a perforated plastic liner and then to cool them. The other is to place the $\mathrm{SO}_{2}$ pad on the grapes, cool the pallet, and wrap it with low-density polyethylene film, leaving the bottom of the pallet open. These two methods were compared for their efficiency in maintaining grape quality and preventing decay for periods ranging from 33 to 117 days. The experiments included 'Redglobe' and 'Zainy' grapes packaged in plastic boxes and 'Thompson Seedless' grapes packaged in cardboard boxes. The quality of the grapes in the trials with plastic boxes was either similar in both packaging methods or better in the wrapped pallet than the liner method. The pedicels, and sometimes the rachis, showed more desiccation in the liners than in the wrapped pallets. Prevention of decay was also better with the wrapped pallets than for storage in liners. However, in the experiment with cardboard boxes, the externally wrapped boxes contained lower levels of $\mathrm{SO}_{2}$, probably because of absorption of $\mathrm{SO}_{2}$ by the cardboard, and the grapes developed more decay and rachis desiccation than in liners inside the cardboard boxes. The method of wrapping grapes after cooling them can have significant advantages over the liner method because of the faster cooling of the grapes and the use of less plastic-based, nonrecyclable materials.
\end{abstract}

$\mathrm{T}$ Table grapes are a nonclimacteric fruit with a low rate of physiological activity (Peynaud and Ribereau-Gayon, 1971) but are subject to serious water loss and decay during postharvest handling (Nelson, 1985). Gray mold caused by the fungus Botrytis cinerea and rachis browning as a result of desiccation are the two main factors that reduce table grape postharvest quality (Nelson, 1985). The means for preventing decay during storage is the use of sulfur dioxide $\left(\mathrm{SO}_{2}\right)$, which was first tried in 1925 (Winkler and Jacob, 1925). In subsequent years, a $\mathrm{SO}_{2}$-releasing pad was developed that consists of sodium metabisulfite grains enclosed in paper-plastic pockets

$\overline{\text { Department of Postharvest Science, Volcani Center, }}$ Agricultural Research Organization, P.O. Box 6, Bet Dagan 50250, Israel

We acknowledge that Ruth Ben-Arie originally proposed the concept of pallet wrapping, which became the standard commercial practice in Israel. We also thank the Chief Scientist of Israel's Ministry of Agriculture and Rural Development and the Fruit Board of Israel for their partial support of this research in the framework of Program 403-0362-02. We must also thank all the growers who contributed fruit for the experiments, and especially Tali Grapes of Moshav Lachish.

${ }^{1}$ Corresponding author. E-mail: slurie43@agri.gov.il. inside a pad. Since the late 1960s a two-stage or dual-release (DR) $\mathrm{SO}_{2}$ generator consisting of formulations that allow quick release plus slow release of the gas have been widely used for table grape storage and transport (Nelson and Ahmedullah, 1976). The DR pad contains sodium metabisulfite enclosed between paper sheets of differing permeability. Moisture within the package of grapes is absorbed by the pads and reacts with the sulfite, releasing $\mathrm{SO}_{2}$. The quickrelease part of the pad gives a flush of $\mathrm{SO}_{2}$, which peaks after $\approx 24 \mathrm{~h}$ and then diminishes in $\approx 1$ week. The slow-release part of the pad emits a low concentration of $\mathrm{SO}_{2}$ over a long period. Laminated pads are a further development in which the salt is impregnated between polymers.

Of interest is how the generator pads behave in different packaging systems. In South Africa, it has been shown that a $\mathrm{SO}_{2}$ concentration around the grapes of 10 to $20 \mathrm{ppm}$ is safe and effective (Laszlo et al., 1981). It was found that concentrations of less than $7 \mathrm{ppm}$ in the fruit did not control decay if the storage temperature fluctuated above $0{ }^{\circ} \mathrm{C}$ and that concentrations higher than $20 \mathrm{ppm}$ could injure the grapes by bleaching. Therefore, an $\mathrm{SO}_{2}$ concentration of 7 to $10 \mathrm{ppm}$ was recommended for long-term storage of grapes (Laszlo et al., 1981).

There are two main concepts in use for packing grapes for extended storage: packing with a $\mathrm{SO}_{2}$ generator pad and fumigation of cold storage chambers with $\mathrm{SO}_{2}$. In the United States during static cold storage, the grapes are subjected to an initial fumigation with $\mathrm{SO}_{2}$ during forcedair cooling and then given weekly fumigations during storage. Packaging with $\mathrm{SO}_{2}$ pads is used for both exporting and static storage in other countries (Lichter et al., 2006). One method of packaging is to pack the grapes with an $\mathrm{SO}_{2}$ generator inside a perforated liner in a box. The liner limits moisture loss from the rachis and berries, and the perforations prevent the humidity from causing water condensation on the grapes. However, this method slows the rapid cooling of the grapes after harvest. A second method is to pack the grapes in a box with an $\mathrm{SO}_{2}$ generator pad, arrange the boxes on a pallet, rapidly cool the grapes to $4{ }^{\circ} \mathrm{C}$ or below, and after they have been in the cold for 1 $\mathrm{d}$, to wrap the pallet with linear lowdensity polyethylene (LLDPE) on all

\begin{tabular}{llll}
\hline $\begin{array}{l}\text { Units } \\
\text { To convert U.S. to SI, } \\
\text { multiply by }\end{array}$ & U.S. unit & SI unit & $\begin{array}{l}\text { To convert SI to U.S., } \\
\text { multiply by }\end{array}$ \\
\hline 29.5735 & $\mathrm{fl} \mathrm{oz}$ & $\mathrm{mL}$ & 0.0338 \\
2.54 & inch(es) & $\mathrm{cm}$ & 0.3937 \\
25.4 & inch(es) & $\mathrm{mm}$ & 0.0394 \\
6.4516 & inch ${ }^{2}$ & $\mathrm{~cm}^{2}$ & 0.1550 \\
0.4536 & $\mathrm{lb}$ & $\mathrm{kg}$ & 2.2046 \\
1 & micron & $\mu \mathrm{m}$ & 1 \\
28.3495 & $\mathrm{oz}$ & $\mathrm{g}$ & 0.0353 \\
28,350 & $\mathrm{oz}$ & $\mathrm{mg}$ & $3.5274 \times 10^{-5}$ \\
1 & $\mathrm{ppm}$ & $\mathrm{mg} \cdot \mathrm{L}^{-1}$ & 1 \\
1 & $\mathrm{ppm}$ & $\mu \mathrm{L}^{-1}$ & 1 \\
$\left({ }^{\circ} \mathrm{F}-32\right) \div 1.8$ & ${ }^{\circ} \mathrm{F}$ & ${ }^{\circ} \mathrm{C}$ & $\left(1.8 \times{ }^{\circ} \mathrm{C}\right)+32$ \\
& & &
\end{tabular}


sides and the top, leaving the bottom of the pallet unwrapped. This wrapping process is mechanized and allows for rapid cooling of the grapes. There is greater free air space inside the resulting large package.

The $\mathrm{SO}_{2}$ generator pads were developed for use in liners inside boxes. The two methods of packing were compared for grape quality during sea shipment and storage for a period of 3 weeks and were found to be comparable (Ben-Arie et al., 1984). However, in recent years, late-season grapes such as 'Redglobe', harvested in September, are being stored for longer periods. In these cases, it is important to find the best method of packaging that will minimize water loss while preventing the decay that would occur if the $\mathrm{SO}_{2}$ level was too low or the $\mathrm{SO}_{2}$ damage that would occur if it was too high. The purpose of the present study, therefore, was to compare two methods of packaging table grapes destined for storage: boxes with perforated liners and palletized boxes wrapped with LLDPE. In addition, in some trials, the dualrelease $\mathrm{SO}_{2}$ pad was compared with a laminated pad. The kinetics of $\mathrm{SO}_{2}$ concentration in the atmosphere around the grapes were monitored, and the quality of the grapes after storage and holding for $3 \mathrm{~d}$ at $20^{\circ} \mathrm{C}$ was examined. The $\mathrm{SO}_{2}$ generators used were commercially available dualrelease and laminated pads. Three grape cultivars were examined, 'Redglobe', 'Thompson Seedless', and 'Zainy', and the storage periods in different experiments ranged from 33 to $117 \mathrm{~d}$.

\section{Materials and methods}

ExPERIMENTAL SETUP. Grapes were obtained from various farms on the day of harvest, during the commercial harvest season. They were cleaned of damaged or decayed berries and packed into plastic boxes containing 5 or $9 \mathrm{~kg}$ grapes. The internal dimensions of the $5-\mathrm{kg}$ boxes were $40.5 \mathrm{~cm}$ long $\times 34.5 \mathrm{~cm}$ wide $\times 16.5$ $\mathrm{cm}$ high with a grid $25 \mathrm{~cm}$ wide $\times 20$ $\mathrm{cm}$ long containing a total of $605 \mathrm{~cm}^{2}$ of ventilated area in the bottom and $384 \mathrm{~cm}^{2}$ in the sides. The internal dimensions of the $9-\mathrm{kg}$ boxes were 52 $\mathrm{cm}$ long $\times 34 \mathrm{~cm}$ wide $\times 18 \mathrm{~cm}$ high with an array of six squares containing a total of $606 \mathrm{~cm}^{2}$ of ventilated area in the bottom and $1130 \mathrm{~cm}^{2}$ in the

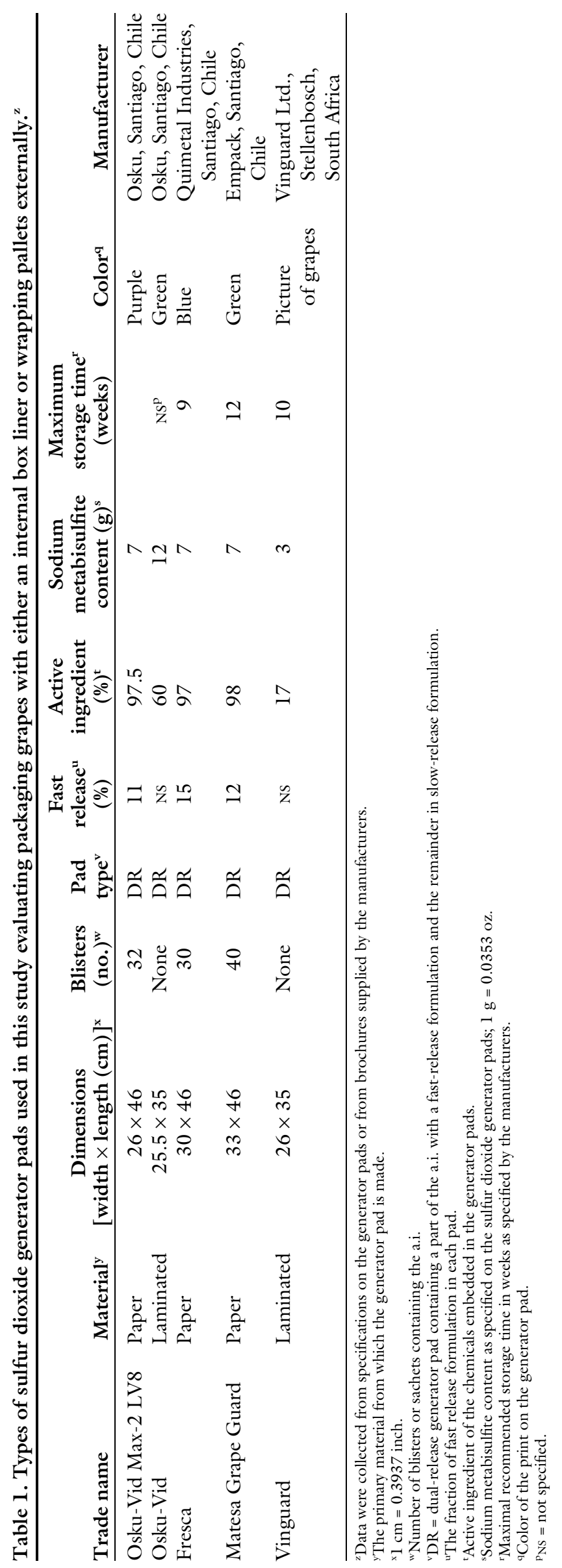


sides. Two methods of packaging were used in this study: 1) bunches were placed in boxes with $30-\mu \mathrm{m}$ high-density polypropylene liners having $0.2 \%$ ventilation (holes of 6- $\mathrm{mm}$ diameter spaced every $12 \mathrm{~cm}$ ) with an $\mathrm{SO}_{2}$ generator pad on top of the bunches; and 2) a unit of three or four stacked plastic boxes of grape bunches, termed a "mini-pallet" (MP), with each box containing a $\mathrm{SO}_{2}$ generator pad. The MP boxes were passively cooled by placing them into a storage room at $0{ }^{\circ} \mathrm{C}, 91 \%$ relative humidity $(\mathrm{RH})$, so that the temperature of the berries was below $3{ }^{\circ} \mathrm{C}$ before the boxes were wrapped the next day. They were wrapped by winding a $50-\mathrm{cm}$ wide, $30-\mu \mathrm{m}$ film of LLDPE around the MP. In each turn, the film was raised by half its width to create a double spiral overlap. Before wrapping, the top of the MP was covered with a high-density polyethylene sheet, slightly larger than the surface of the box, placed on top. The bottom of the MP was left unwrapped and was raised off the floor by placing it on an empty plastic box. As well as two types of packaging, two different types of $\mathrm{SO}_{2}$ generator pads were used: l) a DR pad made of paper layers; and 2) a laminated pad (LM) with a plastic coating. Thus, comparisons were made among two pads in a liner (designated LM liner and DR liner) and two pads in the "mini-pallet" (designated LM-MP and DR-MP). The $\mathrm{SO}_{2}$-generating pads and laminates were obtained from the following manufacturers: Fresca (Quimetal, Santiago, Chile), Matesa (Empack, Santiago, Chile), Osku-VID (Osku, Santiago, Chile), and Vinguard (Vinguard Ltd, Stellenbosch, South Africa). The specifications of the various pads are given in Table 1 . There were three or four replicates for each treatment. In some experiments, $\mathrm{RH}$ was determined inside the MP and liners; the RH values in both methods were in the range of $96 \%$ to $98 \%$ as determined with a Hygro$\log$ (Rotronic AG, Bassersdorf, Switzerland) instrument placed in the boxes.

Three experiments were conducted in different seasons with 'Redglobe' grapes. In addition, one experiment with 'Thompson Seedless' grapes used cardboard boxes, not plastic boxes. The cardboard
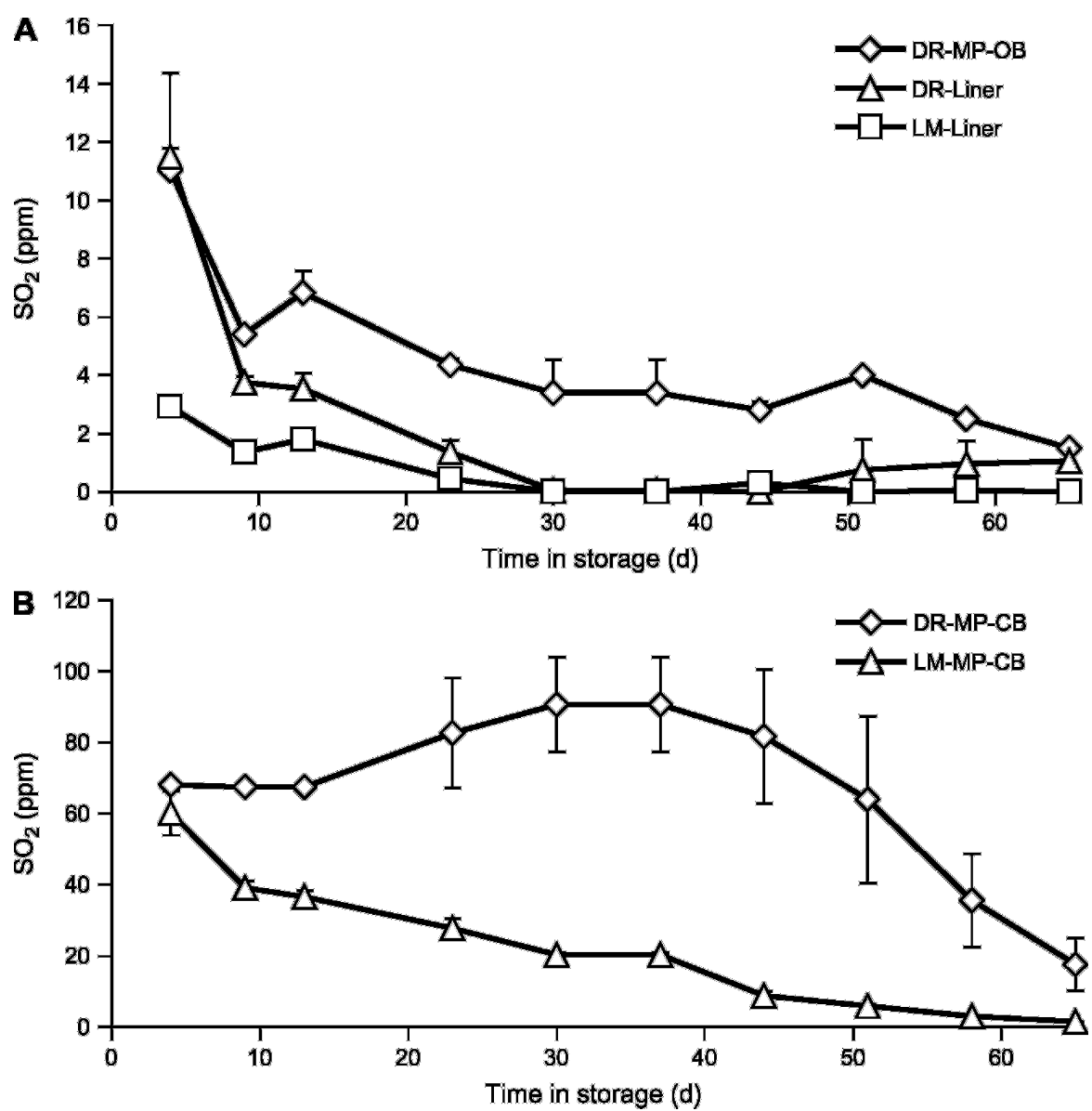

Fig. 1. Sulfur dioxide $\left(\mathrm{SO}_{2}\right)$ concentration around 'Redglobe' grapes stored at $0{ }^{\circ} \mathrm{C}$ $\left(32.0{ }^{\circ} \mathrm{F}\right)$ in plastic boxes with (A) liners inside (liner) or wrapped on the outside and top with linear low-density polyethylene (LLDPE) film in a "mini-pallet" [MP (three stacked plastic boxes containing grapes)] with the bottom left open (OB); (B) wrapped on the outside and top with LLDPE film and the bottom closed with high-density polyethylene film (CB). $\mathrm{SO}_{2}$ pads were either a laminate (LM) or a paper-type dual-release pad (DR) manufactured by Osku (Santiago, Chile). SD is indicated $(\mathrm{n}=4) ; 1 \mathrm{ppm}=1 \mu \mathrm{L} \cdot \mathrm{L}^{-1}$.

boxes measured $37 \mathrm{~cm}$ long $\times 28 \mathrm{~cm}$ wide $\times 12 \mathrm{~cm}$ high and they included a total of $88 \mathrm{~cm}^{2}$ of ventilated area in the bottom and $95 \mathrm{~cm}^{2}$ in the sides. Another experiment was performed with the local cultivar, 'Zainy', packed in $9-\mathrm{kg}$ plastic boxes with DR pads from three different manufacturers.

$\mathrm{SO}_{2}$ ANALYsIs. $\mathrm{SO}_{2}$ levels inside the packages were monitored weekly with an electrochemical sensor fitted with a small pump that operated at a flow rate of $50 \mathrm{~mL} \cdot \mathrm{min}^{-1}$ to sample air from the package into the instrument (Emproco, Ashkelon, Israel). The instrument was connected to silicon tubes inserted into the center of the middle box of each MP replicate, or $10 \mathrm{~cm}$ into the package in each box of the liners, and the connections ensured that air was circulated into the instrument and back to the package. The $\mathrm{SO}_{2}$ detection limit of the instrument was $0.1 \mathrm{ppm}$.

The sulfite content in the berries was determined according to the optimized Monier-Williams distillation method (Association of Official Analytical Chemists International, 2005); 50 berries were sampled from each replicate and frozen for later analysis of sulfite content. After thawing, the berries were homogenized in a blender for $2 \mathrm{~min}$ with one intermission. Thirty grams of homogenized sample were weighed into a round-bottomed sample flask connected to a condensation apparatus, and $15 \mathrm{~mL}$ of $25 \%$ phosphoric acid $\left(\mathrm{H}_{3} \mathrm{PO}_{4}\right)$ was added. The "free" $\mathrm{SO}_{2}$ was released into the apparatus during 15 min with an air stream flowing at 2 $\mathrm{mL} \cdot \mathrm{min}^{-1}$ that bubbled into a collection flask containing $15 \mathrm{~mL}$ of $0.3 \%$ 
Table 2. Comparison of quality of 'Redglobe' grapes held in storage with two different types of sulfur dioxide $\left(\mathrm{SO}_{2}\right)$-releasing pads and with a polyethylene liner inside the box or with wrapping of three boxes together on the outside. ${ }^{\mathrm{z}}$

\begin{tabular}{|c|c|c|c|c|c|c|}
\hline Treatment $^{\mathbf{y}}$ & \multicolumn{2}{|c|}{$\begin{array}{l}\text { Rachis desiccation } \\
(1-5 \text { scale })^{x}\end{array}$} & \multicolumn{2}{|c|}{$\begin{array}{l}\text { Pedicel desiccation } \\
(1-5 \text { scale })^{x}\end{array}$} & $\begin{array}{c}\mathrm{SO}_{2} \text { damage } \\
(1-5 \text { scale })^{\mathrm{w}} \\
\text { Storage }\end{array}$ & $\begin{array}{c}\text { Healthy bunches } \\
\text { (\%) } \\
\text { Shelf life }\end{array}$ \\
\hline Control-OB & $2.2 \pm 0.2 \mathrm{a}^{\mathrm{u}}$ & $2.7 \pm 0.1 \mathrm{a}$ & $2.6 \pm 0.1 \mathrm{a}$ & $3.4 \pm 0.2 \mathrm{a}$ & $1.0 \pm 0.0 \mathrm{~b}$ & $0 \mathrm{~b}$ \\
\hline DR-MP-OB & $2.3 \pm 0.2 \mathrm{a}$ & $2.8 \pm 0.4 \mathrm{a}$ & $2.5 \pm 0.4 \mathrm{a}$ & $3.3 \pm 0.6 a$ & $1.0 \pm 0.0 \mathrm{~b}$ & $81 \pm 21 \mathrm{a}$ \\
\hline LM-Liner-OB & $2.4 \pm 0.2 \mathrm{a}$ & $2.7 \pm 0.1 \mathrm{a}$ & $2.9 \pm 0.2 \mathrm{a}$ & $3.7 \pm 0.2 \mathrm{a}$ & $1.0 \pm 0.0 \mathrm{~b}$ & $69 \pm 17 a$ \\
\hline DR-Liner-OB & $2.3 \pm 0.3 a$ & $2.8 \pm 0.3 a$ & $2.7 \pm 0.3 a$ & $3.7 \pm 0.1 \mathrm{a}$ & $1.0 \pm 0.0 \mathrm{~b}$ & $77 \pm 38 a$ \\
\hline
\end{tabular}

${ }^{z}$ The storage time was $65 \mathrm{~d}$ of storage at $0{ }^{\circ} \mathrm{C}\left(32.0^{\circ} \mathrm{F}\right)$ and $3 \mathrm{~d}$ at $20^{\circ} \mathrm{C}\left(68.0{ }^{\circ} \mathrm{F}\right)$. Quality measurements included rachis and pedicel desiccation, SO $\mathrm{O}_{2}$ damage, and the percentage of bunches with one or no decayed berries at the end of storage and the $3 \mathrm{~d}$ of shelf life.

${ }^{y}$ Control was a mini-pallet (MP [a unit of three stacked plastic boxes containing grapes wrapped around the top and sides with $30-\mu \mathrm{m}$-thick ( $\left.30 \mu \mathrm{m}\right)$ film of linear low-density polyethylene] without $\mathrm{SO}_{2}$-generator pads and with the pallet open at the bottom $(\mathrm{OB}) ; \mathrm{DR}=$ dual-release $\mathrm{SO}_{2}$ generator pad; $\mathrm{LM}=$ laminated $\mathrm{SO} \mathrm{O}_{2}$-generator pad; liner $=$ $30-\mu \mathrm{m}$ high-density polyethylene bag having $0.2 \%$ ventilation [holes $6 \mathrm{~mm}(0.24 \mathrm{inch})$ diameter spaced every $12 \mathrm{~cm}(4.7$ inches $)$ ] placed inside each box; $\mathrm{CB}=$ pallet closed at the bottom.

${ }^{\mathrm{x}} \mathrm{l}=$ rachis and pedicels full and green as at harvest; 2 = slight browning; $3=$ browning of rachis and pedicels but no shriveling; $4=$ browning and some shriveling; $5=$ both rachis and pedicels dry and brown. A rating greater than 3 was considered unmarketable.

${ }^{w}$ Rated according to the number of berries per replicate ( 10 bunches) that suffered bleaching: $1=$ no apparent bleaching; $2=$ two to five berries; $3=$ six to 10 berries; $4=11$ to 20 berries; 5 = over 20 bleached berries.

vStorage was for $65 \mathrm{~d}$ at $0{ }^{\circ} \mathrm{C}$ and shelf life was $3 \mathrm{~d}$ at $20^{\circ} \mathrm{C}$.

"Values in columns followed by different letters indicate significant differences according to analysis of variance with the Student-Newman-Keuls test at $P<0.05$.

hydrogen peroxide $\left(\mathrm{H}_{2} \mathrm{O}_{2}\right)$ titrated to $\mathrm{pH} 7$ with $0.01 \mathrm{~N}$ sodium hydroxide $(\mathrm{NaOH})$. The solution was supplemented with one drop of the indicator dyes methyl red and methylene blue (100 and $50 \mathrm{mg}$, respectively) in $100 \mathrm{~mL}$ of $50 \%$ ethanol solution. "Bound" $\mathrm{SO}_{2}$ was released from the sample after replacing the $\mathrm{H}_{2} \mathrm{O}_{2}$ solution and boiling the sample for $15 \mathrm{~min}$. The condensation apparatus was cooled to $10{ }^{\circ} \mathrm{C}$. The samples were titrated with $0.01 \mathrm{~N}$ $\mathrm{NaOH}$ and the amount of sulfites (in milligrams per liter) in each fraction was calculated by multiplying the titration volume by a factor of 10.6.

QUALITY ANALYSIS OF FRUIT. At each removal from storage, the boxes were transferred to $20{ }^{\circ} \mathrm{C}, 80 \% \mathrm{RH}$ for $3 \mathrm{~d}$, after which 10 bunches from each box were examined individually as previously described (Lichter et al., 2005). Each bunch was rated for desiccation, $\mathrm{SO}_{2}$ damage, and decay. Desiccation and $\mathrm{SO}_{2}$ damage were assessed on an index rating of 1 to 5 . Desiccation ratings were $1=$ rachis and pedicels green and full as at harvest; 2 = slight browning; $3=$ browning of rachis and pedicels but no shriveling; 4 = browning and some shriveling; and $5=$ both rachis and pedicels dry and brown. An index rating above 3 for desiccation was considered unmarketable. $\mathrm{SO}_{2}$ ratings were defined according to the number of berries per replicate that suffered bleaching: $1=$ no apparent bleaching; 2 = two to five berries; 3 = six to 10 berries; $4=11$ to 20 berries; and $5=$ over 20 bleached berries per 10 bunches. Healthy bunches were defined as having only one or no decayed berries, and the percentage of such bunches in each box was determined.

Statistical analysis. Statistical analysis was routinely conducted with the Instat (ver. 3.06; GraphPad, San Diego, CA) by one-way analysis of variance with the Student-Newman Keules posttest at $P<0.05$. Transformation to square root of arcsine

values was applied to the percentages of healthy berries.

\section{Results and discussion}

'Redglobe'. In the first experiment on 'Redglobe' grapes, Osku DR pads were compared with an Osku LM pad in liners and in MP.

An additional two treatments in this experiment tested LM and DR pads in an MP configuration but with the bottom of the pallet closed (designated CB). There was also a control

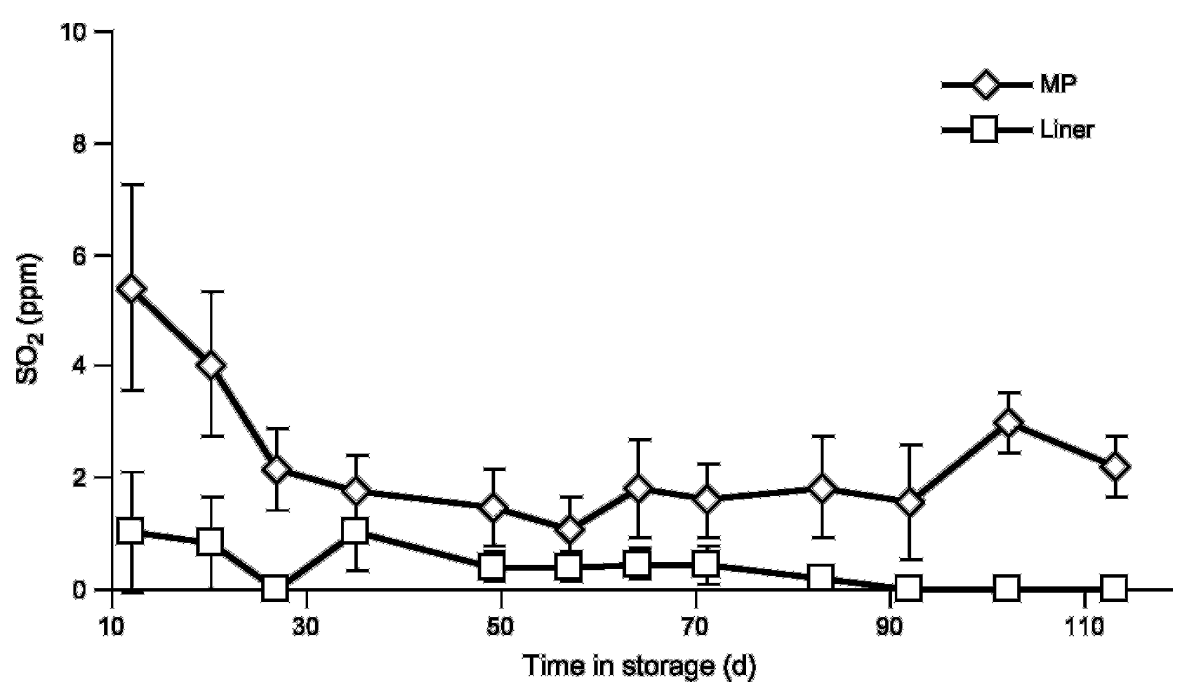

Fig. 2. Sulfur dioxide $\left(\mathrm{SO}_{2}\right)$ concentration around 'Redglobe' grapes stored at $0{ }^{\circ} \mathrm{C}$ $\left(32.0^{\circ} \mathrm{F}\right)$ in plastic boxes with liners inside (liner) or wrapped on the outside with linear low-density polyethylene in a "mini-pallet" [MP (three stacked plastic boxes containing grapes)]. The $\mathrm{SO}_{2}$ generator pad was a dual-release type (DR) manufactured by Osku (Santiago, Chile). SD is indicated $(\mathrm{n}=4) ; 1 \mathrm{ppm}=1 \mu \mathrm{L} \cdot \mathrm{L}^{-1}$. 
without any $\mathrm{SO}_{2}$-generating pad packaged in MP. The results showed that when the bottom of the pallet was closed, the level of $\mathrm{SO}_{2}$ around the grapes was much higher than with either an MP with an open bottom (MP-OB) or in boxes with liners (Fig. 1). After $4 \mathrm{~d}$, the $\mathrm{SO}_{2}$ level was above $60 \mathrm{ppm}$ in MP-CB with either DR or LM pads, and this increased to 90 ppm after $30 \mathrm{~d}$ with the DR pad, whereas in MP-CB with $\mathrm{LM}, \mathrm{SO}_{2}$ levels decreased to $20 \mathrm{ppm}$. By $65 \mathrm{~d}$, the $\mathrm{SO}_{2}$ level in the closed-bottom MP containing a LM pad was below 2 ppm compared with $17 \mathrm{ppm}$ in the same packaging format with DR pads. In contrast, the $\mathrm{SO}_{2}$ in the MP-OB boxes started at a level of $11.5 \mathrm{ppm}$ after $4 \mathrm{~d}$ and reached a level of 1.5 ppm after $65 \mathrm{~d}$ with some fluctuations. In liners with $\mathrm{LM}$ pads, $\mathrm{SO}_{2}$ declined to below the detection level after $30 \mathrm{~d}$. With the DR pad in the liners (DR liner), the $\mathrm{SO}_{2}$ level decreased from $11 \mathrm{ppm}$ to below the detection limit within $30 \mathrm{~d}$ in two subsequent measurements, but in three later measurements, levels of 0.8 to $1.1 \mathrm{ppm}$ were recorded.

In this trial, grape quality was inspected after 43 or $65 \mathrm{~d}$. On the first removal from storage, after $43 \mathrm{~d}$, the untreated control contained $4 \%$ of healthy bunches compared with $100 \%$ in all other treatments. After $65 \mathrm{~d}$ in cold storage and $3 \mathrm{~d}$ at $20^{\circ} \mathrm{C}$, decay appeared, but there were still $81 \%$ of healthy bunches in the MPOB treatment and $69 \%$ in the LM liner treatment (Table 2). The grapes in the MP-CB treatments were $100 \%$ healthy but had high levels of $\mathrm{SO}_{2}$ damage, making them unmarketable. The damage was more extensive in treatments with DR pads than in those with LM. The latter did not differ statistically from the MP-OB or liner treatments without damage. There was no $\mathrm{SO}_{2}$ damage in either the MP-OB treatments or the liners in this experiment or in the other trials reported here. The rachis and pedicels were less desiccated in the MP-CB treatments than either the MP-OB or the liners. The most desiccation was found in the liners.

In the second experiment with 'Redglobe', the grapes were stored for $117 \mathrm{~d}$ with an Osku DR pad (Fig. 2 ). In the MP treatment, the level of $\mathrm{SO}_{2}$ was $\approx 5 \mathrm{ppm}$ after $12 \mathrm{~d}$ of storage, and this decreased to $2 \mathrm{ppm}$ after $27 \mathrm{~d}$, after which it was maintained at 1 to $3 \mathrm{ppm}$ during the next 3 months. The level of $\mathrm{SO}_{2}$ in liners with the same pad was below $1 \mathrm{ppm}$ and it declined to below the detection limit after 3 months. The total levels of $\mathrm{SO}_{2}$ residues after shelf life in the $\mathrm{MP}$ and liner treatments were 4.5 and $3.4 \mathrm{ppm}$, respectively. The MP treatment had $69 \%$ healthy bunches compared with none in the liner treatment (Table 3 ). The desiccation of rachis in the liners was significantly worse than in the MP treatment.

A maximum allowable concentration of $\mathrm{SO}_{2}$ residues in table grapes has been set to 10 ppm (U.S. Government Printing Office, 1986). In grapes, the $\mathrm{SO}_{2}$ is dissolved into the cytoplasm as sulfite and bisulfite, depending on the $\mathrm{pH}$ (Peiser and Yang, 1985). After fumigation of 30 min, sulfite and bisulfate were converted to sulfate in the fruit within $24 \mathrm{~h}$ (Peiser and Yang, 1985). Sulfates are natural components of grapes, and their presence has no toxicological or health implications. However, the oxidation capacity of grape berries is limited, and the internal conversion of sulfite to sulfate can be exhausted. In this trial with the longest storage time of $113 \mathrm{~d}$, it was found that $\mathrm{SO}_{2}$ residue levels were 4.5 and $3.4 \mathrm{ppm}$ for the MP and liner treatments, respectively. Therefore, although the levels of $\mathrm{SO}_{2}$ around the grapes in the MP packaging method were higher

Table 3. Comparison of 'Redglobe' grape quality stored with a dual-release (DR) sulfur dioxide $\left(\mathrm{SO}_{2}\right)$ generator pad in either boxes wrapped with polyethylene from the outside or with a polyethyelene liner inside the boxes. ${ }^{z}$

\begin{tabular}{|c|c|c|c|c|c|}
\hline \multirow[b]{2}{*}{ Treatment $^{\mathrm{y}}$} & \multicolumn{2}{|c|}{$\begin{array}{l}\text { Rachis desiccation } \\
\qquad(1-5 \text { scale })^{x}\end{array}$} & \multicolumn{2}{|c|}{$\begin{array}{l}\text { Pedicel desiccation } \\
\qquad(1-5 \text { scale })^{\mathrm{x}}\end{array}$} & \multirow{2}{*}{$\begin{array}{c}\text { Healthy bunches } \\
(\%) \\
\text { Shelf life }\end{array}$} \\
\hline & Storage $^{w}$ & Shelf life $^{\mathrm{w}}$ & Storage & Shelf life & \\
\hline DR-MP & $2.3 \pm 0.4 \mathrm{~b}^{\mathrm{v}}$ & $3.3 \pm$ & $2.3 \pm 0.4 \mathrm{~b}$ & 3.4 & $69 \pm 4$ \\
\hline DR-Liner & $3.2 \pm 0.3 \mathrm{a}$ & $3.8 \pm 0.4 \mathrm{a}$ & $4.0 \pm 0 \mathrm{a}$ & $4.5 \pm 0.4 \mathrm{a}$ & $0 \mathrm{~b}$ \\
\hline
\end{tabular}

${ }^{\mathrm{z}}$ Storage was for $117 \mathrm{~d}$ at $0{ }^{\circ} \mathrm{C}\left(32.0^{\circ} \mathrm{F}\right)$ and $3 \mathrm{~d}$ at $20^{\circ} \mathrm{C}\left(68.0^{\circ} \mathrm{F}\right)$. Quality measurements included rachis and pedicel desiccation and the percentage of bunches with one or no decayed berries at the end of storage and the $3 \mathrm{~d}$ of shelf life.

"Treatments were with a DR SO 2 generator pad in either a mini-pallet (MP [a unit of three stacked plastic boxes containing grapes wrapped around the top and sides with $30-\mu \mathrm{m}$-thick $(30 \mu \mathrm{m})$ film of linear low-density polyethylene]) or in a liner (liner), which is a 30- $\mu \mathrm{m}$ high-density polyethylene bag having $0.2 \%$ ventilation [holes 6 $\mathrm{mm}(0.24$ inch $)$ diameter spaced every $12 \mathrm{~cm}$ ( 4.7 inches $)]$ placed inside each box.

${ }^{\mathrm{x}} \mathrm{l}=$ rachis and pedicels full and green as at harvest; $2=$ slight browning; $3=$ browning of rachis and pedicels but no shriveling; 4 = browning and some shriveling; 5 = both rachis and pedicels dry and brown. A rating greater than 3 was considered unmarketable.

wStorage was for $117 \mathrm{~d}$ at $0{ }^{\circ} \mathrm{C}$ and shelf life was $3 \mathrm{~d}$ at $20^{\circ} \mathrm{C}$.

Values in columns followed by different letters indicate significant differences according to analysis of variance with the Student-Newman-Keuls test at $P<0.05$.

Table 4. Comparison of quality of 'Redglobe' grapes stored in boxes with an internal polyethylene liner or as three boxes of grapes wrapped on the outside and with either a laminate or dual-release sulfur dioxide $\left(\mathrm{SO}_{2}\right)$ generator pad.

\begin{tabular}{lccc}
\hline Treatment $^{\mathrm{y}}$ & $\begin{array}{c}\text { Rachis desiccation } \\
(\mathbf{1}-\mathbf{5} \text { scale })^{\mathrm{x}}\end{array}$ & $\begin{array}{c}\text { Pedicel desiccation } \\
(\mathbf{1}-\mathbf{5} \text { scale })^{\mathrm{x}}\end{array}$ & $\begin{array}{c}\text { Healthy bunches } \\
\mathbf{( \% )}\end{array}$ \\
\hline Liner & $3.2 \pm 0.2^{\mathrm{w}}$ & $4.2 \pm 0.4$ & $9 \pm 16 \mathrm{c}^{\mathrm{y}}$ \\
LM-Liner & $2.7 \pm 0.2$ & $4.1 \pm 0.4$ & $45 \pm 10 \mathrm{ab}$ \\
DR-Liner & $2.9 \pm 0.2$ & $3.9 \pm 0.2$ & $46 \pm 50 \mathrm{ab}$ \\
MP & $2.9 \pm 0.5$ & $3.9 \pm 0.5$ & $29 \pm 30 \mathrm{~b}$ \\
LM-MP & $2.6 \pm 0.4$ & $3.6 \pm 0.5$ & $70 \pm 14 \mathrm{a}$ \\
DR-MP & $2.9 \pm 0.8$ & $3.8 \pm 0.5$ & $79 \pm 21 \mathrm{a}$ \\
& NS & NS & \\
\hline
\end{tabular}

${ }^{2}$ Storage was for $62 \mathrm{~d}$ at $0{ }^{\circ} \mathrm{C}\left(32.0^{\circ} \mathrm{F}\right)$ and $3 \mathrm{~d}$ shelf life at $20^{\circ} \mathrm{C}\left(68.0^{\circ} \mathrm{F}\right)$ with quality measured at the end of the $3 \mathrm{~d}$. Quality measurements included rachis and pedicel desiccation and the percentage of bunches with one or no decayed berries at the end of storage and the $3 \mathrm{~d}$ of shelf life.

${ }^{y}$ Treatments were with boxes with a liner (liner), which is a 30 - $\mu \mathrm{m}$-thick $(30 \mu \mathrm{m})$ high-density polvethylene bag having $0.2 \%$ ventilation [holes $6-\mathrm{mm}(0.24 \mathrm{inch})$ diameter spaced every $12 \mathrm{~cm}(4.7$ inches $)$ ] placed inside each box or with a mini-pallet (MP; a unit of three stacked plastic boxes containing grapes wrapped around the top and sides with 30- $\mu \mathrm{m}$ film of linear low-density polyethylene). In each type of box, there was no sulfur dioxide $\mathrm{SO}_{2}$ generator pad, a laminated pad (LM), or a dual-release (DR) pad.

${ }^{\mathrm{x}} \mathrm{I}=$ rachis and pedicels full and green as at harvest; 2 = slight browning; $3=$ browning of rachis and pedicels but no shriveling; $4=$ browning and some shriveling; $5=$ both rachis and pedicels dry and brown. A rating greater than 3 was considered unmarketable.

"Values in columns followed by different letters indicate significant differences according to analysis of variance with the Student-Newman-Keuls test at $P<0.05 ;$ NS $=$ no significant differences. 
than with liners, the residue levels are not expected to exceed the allowable limit.

The third experiment with 'Redglobe' grapes was conducted for $65 \mathrm{~d}$. With Osku DR pads in a MP, the $\mathrm{SO}_{2}$ level from day 11 to day 40 was 3 to 4 ppm, whereas in boxes with liners, it was 1 to $2.5 \mathrm{ppm}$. At day 50 , the $\mathrm{SO}_{2}$ level in the MP was 1.8 and that in the liners was $0.6 \mathrm{ppm}$, whereas at the end of storage, the $\mathrm{MP} \mathrm{SO}$ level was 0.6 ppm and that in the liners $0.1 \mathrm{ppm}$. The level of $\mathrm{SO}_{2}$ from a Vinguard LM pad, either in MP or boxes with liners, fell below the detection limit within the timeframe of measurement (11 to $64 \mathrm{~d}$ ). Further examination of the properties of this laminate showed that it released $\mathrm{SO}_{2}$ only in the first week of storage (data not shown). Grape quality was analyzed after $65 \mathrm{~d}$ (Table 4). The presence of an LM or a DR pad increased the percentage of healthy bunches in liners from 9\% with no pad to $45 \%$ or $46 \%$, respectively. In the MP treatment, the proportion of healthy bunches increased from $29 \%$ without a pad to $70 \%$ or $79 \%$ for the LM or DR pads, respectively. There was a tendency for the grapes in the liners to have dryer rachis and pedicels, but the differences between pairs of treatments were usually not significant.

In all three trials, the levels of $\mathrm{SO}_{2}$ were higher inside the MP packaging than in the liners. There are a number of explanations for the differences in $\mathrm{SO}_{2}$ release from the same type of $\mathrm{SO}_{2}$-generating pad in the two different packaging systems. One is that although the MP was open on the bottom, it was still less permeable to $\mathrm{SO}_{2}$ than the liner, whose surface area contained $0.2 \%$ of perforations around the grapes. However, it is also possible that because we began monitoring the $\mathrm{SO}_{2}$ levels several days after storage was initiated, we might have missed a peak of $\mathrm{SO}_{2}$ emission from the pads in the liners. The cooling rate of grapes in the liners was slower than that of unwrapped grapes, and in the MP method, they were wrapped only after they had cooled to $4{ }^{\circ} \mathrm{C}$ or lower. In previous experiments, it was established that in the experimental storage rooms, it took grapes inside $0.2 \%$ perforated liners $44 \mathrm{~h}$ to reach $0{ }^{\circ} \mathrm{C}$, whereas those without the liners cooled to $0{ }^{\circ} \mathrm{C}$ after $18 \mathrm{~h}$ (R. Ben-Arie, unpublished data). Warm grapes respire more than cold ones and would cause release of $\mathrm{SO}_{2}$ from the pads at the beginning of the storage period. Most of the measurements of $\mathrm{SO}_{2}$ were performed after $6 \mathrm{~d}$ or more of storage, and these measurements were likely to miss any early $\mathrm{SO}_{2}$ burst.

'THOMPSON SEEDLES'. 'Thompson Seedless' grapes were stored for $45 \mathrm{~d}$ in cardboard boxes

Table 5. A comparison of average sulfur dioxide $\left(\mathrm{SO}_{2}\right)$ level over the course of $45 \mathrm{~d}$ of $0{ }^{\circ} \mathrm{C}\left(32.0{ }^{\circ} \mathrm{F}\right)$ storage of 'Thompson Seedless' grapes and quality of the grapes after $45 \mathrm{~d}$ at $0{ }^{\circ} \mathrm{C}$ and $3 \mathrm{~d}$ at $20^{\circ} \mathrm{C}\left(68.0{ }^{\circ} \mathrm{F}\right)$ when stored with either a polyethylene bag inside the box or with three boxes wrapped on the outside in polyethylene. ${ }^{z}$

\begin{tabular}{lcccc}
\hline Treatment $^{\mathbf{y}}$ & $\begin{array}{c}\text { SO }_{2} \text { level } \\
(\mathbf{p p m})^{\mathbf{x}}\end{array}$ & $\begin{array}{c}\text { Rachis desiccation } \\
(\mathbf{1}-\mathbf{5} \text { scale })^{\mathbf{w}}\end{array}$ & $\begin{array}{c}\text { Pedicel desiccation } \\
(\mathbf{1}-\mathbf{5} \text { scale })^{\mathbf{w}}\end{array}$ & $\begin{array}{c}\text { Healthy } \\
\text { bunches (\%) }\end{array}$ \\
\hline Liner & & $2.7 \pm 0.1 \mathrm{ab}$ & $3.2 \pm 0.1 \mathrm{ab}$ & $0 \mathrm{c}$ \\
LM-Liner & $0.5 \pm 0.4 \mathrm{~b}^{\mathrm{v}}$ & $2.4 \pm 0.1 \mathrm{abc}$ & $2.6 \pm 0.1 \mathrm{~b}$ & $87 \pm 8 \mathrm{a}$ \\
DR-Liner & $4.7 \pm 0.8 \mathrm{a}$ & $2.1 \pm 0.2 \mathrm{c}$ & $2.6 \pm 0.0 \mathrm{~b}$ & $62 \pm 10 \mathrm{ab}$ \\
MP & & $2.7 \pm 0.0 \mathrm{ab}$ & $3.1 \pm 0.1 \mathrm{ab}$ & $0 \mathrm{c}$ \\
LM-MP & $0.4 \pm 0.3 \mathrm{~b}$ & $3.1 \pm 0.1 \mathrm{a}$ & $3.7 \pm 0.2 \mathrm{a}$ & $54 \pm 12 \mathrm{ab}$ \\
DR-MP & $1.9 \pm 0.4 \mathrm{~b}$ & $2.9 \pm 0.2 \mathrm{a}$ & $3.6 \pm 0.1 \mathrm{ab}$ & $28 \pm 24 \mathrm{~b}$ \\
\hline
\end{tabular}

${ }^{\mathrm{z}} \mathrm{SO}_{2}$ was determined every week. Quality measurement at the end of storage and shelf life include rachis and pedicel desiccation and the percentage of bunches with no decayed berries.

yTreatments were with boxes with a liner (liner), which is 30 - $\mu \mathrm{m}$-thick $(30 \mu \mathrm{m})$ high-density polyethylene bag having $0.2 \%$ ventilation [holes of $6-\mathrm{mm}(0.24 \mathrm{inch})$ diameter spaced every $12 \mathrm{~cm}(4.7$ inches $)$ ] placed inside each box or with a mini-pallet (MP; a unit of three stacked plastic boxes containing grapes wrapped around the top and sides with $30-\mu \mathrm{m}$ film of linear low-density polyethylene). In each type of box, there was no $\mathrm{SO}_{2}$ generator pad, a laminated pad (LM), or a dual-release (DR) pad.

${ }^{x} 1 \mathrm{ppm}=1 \mu \mathrm{L} \cdot \mathrm{L}^{-1}$.

${ }^{\mathrm{w}} \mathrm{l}=$ rachis and pedicels full and green as at harvest; 2 = slight browning; $3=$ browning of rachis and pedicels but no shriveling; 4 = browning and some shriveling; 5 = both rachis and pedicels dry and brown. A rating greater than 3 was considered unmarketable.

Values in columns followed by different letters indicate significant differences according to analysis of variance with the Student-Newman-Keuls test at $P<0.05$.

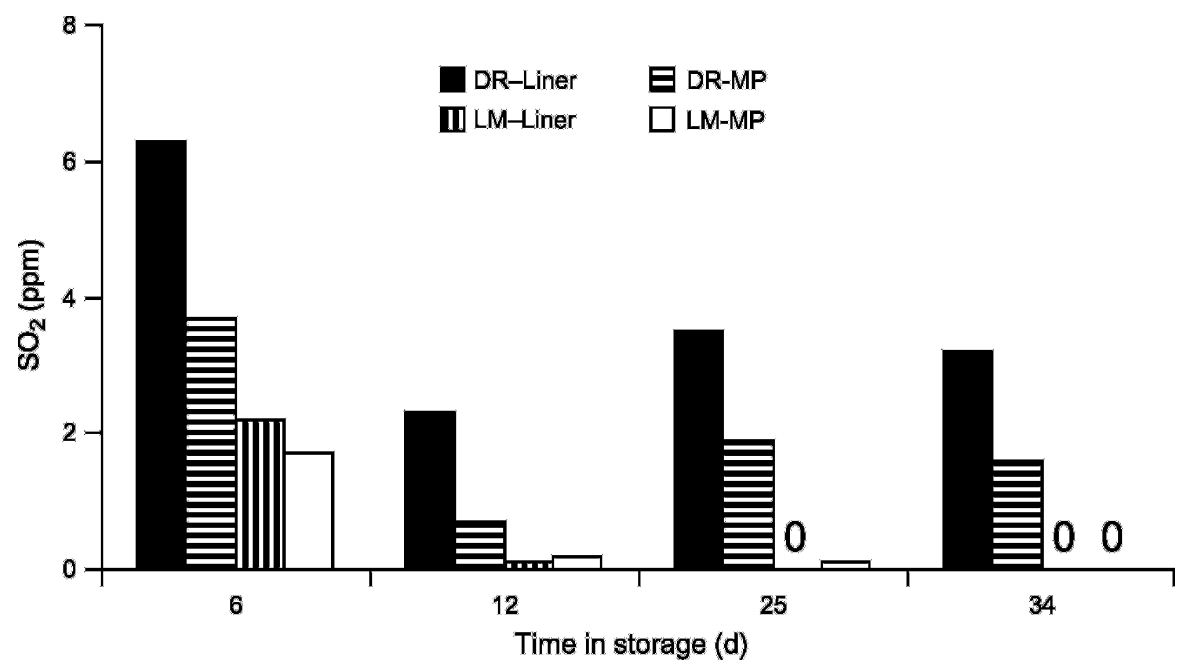

Fig. 3. Sulfur dioxide $\left(\mathrm{SO}_{2}\right)$ concentration around 'Thompson Seedless' grapes stored at $0{ }^{\circ} \mathrm{C}\left(32.0^{\circ} \mathrm{F}\right)$ in cardboard boxes with liners inside (liner) or wrapped on the outside with linear low-density polyethylene (LLDPE) in a "mini-pallet" [MP (three stacked plastic boxes containing grapes)]. $\mathrm{SO}_{2}$ pads were either a plastic laminate (LM) manufactured by Vinguard Ltd. (Stellenbosch, South Africa) or a dual-release pad (DR) manufactured by Osku (Santiago, Chile) $(\mathbf{n}=3)$; $1 \mathrm{ppm}=1 \mu \mathrm{L} \cdot \mathrm{L}^{-1}$. 
packaging method (not shown). The $\mathrm{SO}_{2}$ content in the boxes with liners or in the boxes wrapped in the MP format showed different kinetics from those in the experiments with plastic boxes (Fig. 3 compared with Fig. 1 or 2). For example, after $34 \mathrm{~d}$, the $\mathrm{SO}_{2}$ level in the MP format was only $1.6 \mathrm{ppm}$ compared with $3.2 \mathrm{ppm}$ measured in the liner. The possible explanation for this situation is that the cardboard absorbed $\mathrm{SO}_{2}$, whereas the liner separating the grapes and the $\mathrm{SO}_{2}$ pad from the cardboard prevented this absorption. The first measurement of $\mathrm{SO}_{2}$ in the $\mathrm{MP}$ or liner format with a Vinguard LM pad was $\approx 2$ ppm after $6 \mathrm{~d}$ in storage, but in later measurements, $\mathrm{SO}_{2}$ was not detected. As discussed previously with regard to the third 'Redglobe' experiment, the Vinguard LM pad was found to operate as a fast-release pad so that $\mathrm{SO}_{2}$ levels exceeded 100 ppm during the first $3 \mathrm{~d}$ of storage and declined to very low levels later (data not shown). Table 5 shows the quality of the 'Thompson Seedless' grapes after $45 \mathrm{~d}$ of storage at $0{ }^{\circ} \mathrm{C}$ and $3 \mathrm{~d}$ at $20^{\circ} \mathrm{C}$. As expected, there were no healthy bunches among the control grapes with no $\mathrm{SO}_{2}$ pad. The best control over decay in this experiment was achieved with the liners and the LM generator pad $(87 \%$ healthy bunches) followed by liners with Osku DR pads $(62 \%$ healthy bunches). The MP format gave lower efficacy with $54 \%$ and $28 \%$ of healthy bunches with the LM pad and the DR pad, respectively. Desiccation indices were high in the MP treatments with both types of pads. Interestingly, there was no apparent difference in the quality of rachis between the liner and the MP controls without $\mathrm{SO}_{2}$ pads, suggesting that the presence and amount of $\mathrm{SO}_{2}$ was the major factor that determined the appearance of the rachis. It should be noted also that in this experiment, the rachis were much thicker than normal rachis of 'Thompson Seedless', most likely because of vineyard treatments.

The results of this experiment with cardboard boxes were different from those of the trials of 'Redglobe' and plastic boxes. The trials with plastic boxes showed higher $\mathrm{SO}_{2}$ levels in the MP than in the liners, but with cardboard boxes, this trend was reversed. It has been recognized that when weekly $\mathrm{SO}_{2}$ fumigation is used, like in the United States, instead of $\mathrm{SO}_{2}$ pads, it is necessary to take into account the absorption of fumigants by packaging materials. It was found, for example, that grapes packed in polystyrene foam boxes absorbed $50 \%$ less $\mathrm{SO}_{2}$ than those packed in wooden boxes (Harvey et al., 1988). In the present trial, the cardboard boxes were in contact with the grapes and the $\mathrm{SO}_{2}$ pad in the MP packaging, whereas the liner separated the grapes and the $\mathrm{SO}_{2}$ pad from the cardboard box. Thus, more $\mathrm{SO}_{2}$ could be absorbed by the cardboard box in the MP than in the liner-
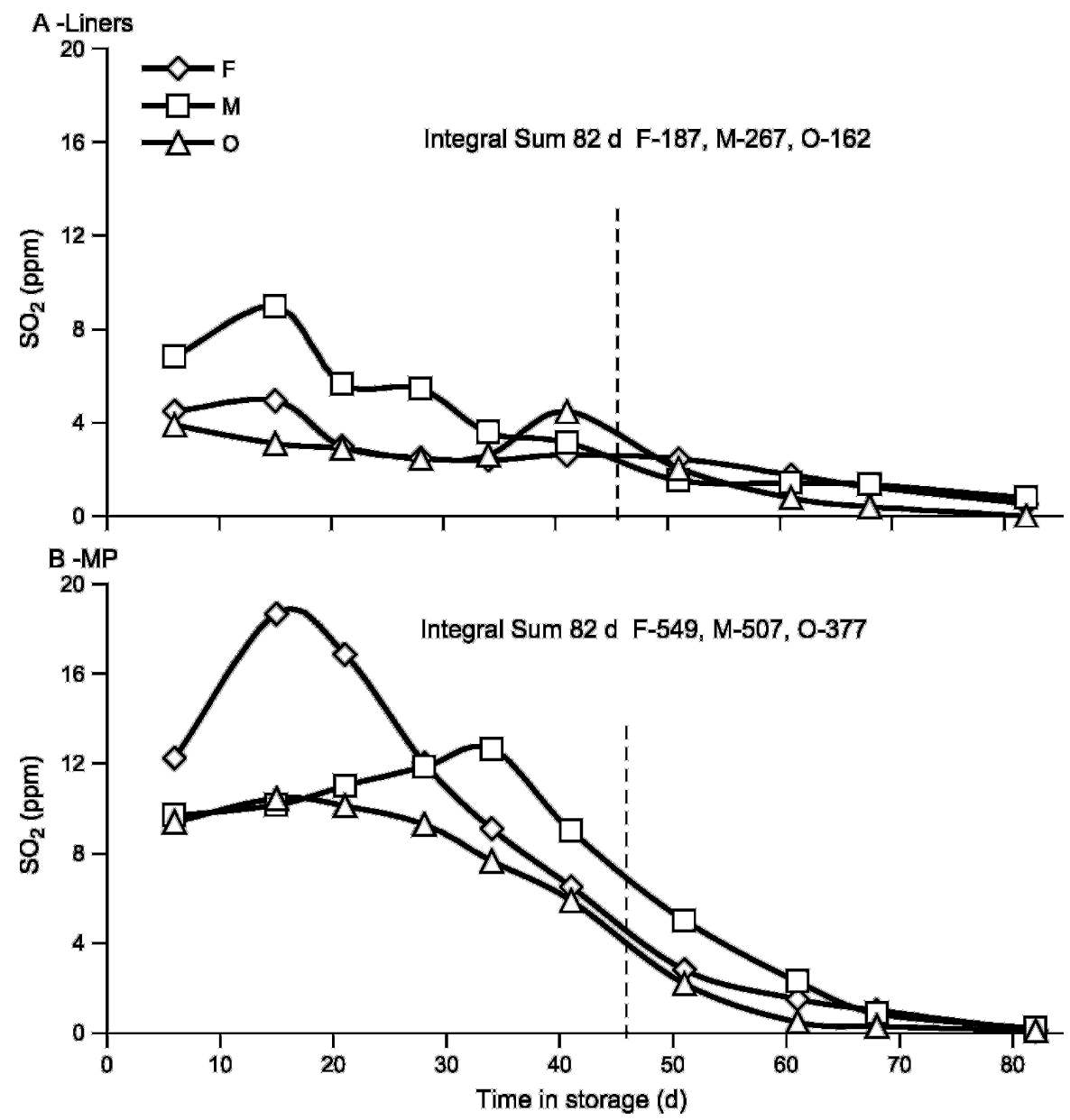

Fig. 4. Sulfur dioxide $\left(\mathrm{SO}_{2}\right)$ concentration around 'Zainy' grapes stored at $0{ }^{\circ} \mathrm{C}$ $\left(32.0{ }^{\circ} \mathrm{F}\right)$ in plastic boxes with dual-release pads (DR) from three manufacturers: Fresca [F (Quimetal Industries, Santiago, Chile)], Matesa [M (Empack, Santiago, Chile)], and Osku [O (Osku, Santiago, Chile)]. Bunches were placed in liners inside each box (A-Liners) or replicates of three boxes were wrapped on the outside with linear low-density polyethylene in a "mini-pallet" format [MP (three stacked plastic boxes containing grapes)] with the bottom of the MP left open. The broken line indicates up to what time in storage there were significant differences in $\mathrm{SO}_{2}$ levels measured in liners compared with "mini-pallets." "Integral sum" designates the accumulated amount of $\mathrm{SO}_{2}$ measured inside each treatment from 6 to $82 \mathrm{~d}$ of storage. For example, the number F-187 corresponds to a total of $187 \mathrm{ppm}$ calculated as the integral, which accumulated in the $\mathrm{F}$ treatment over the entire period of storage $\left(1 \mathrm{ppm}=1 \mu \mathrm{L} \cdot \mathrm{L}^{-1}\right)$. 
during $82 \mathrm{~d}$ of cold storage (Fig. 4). In the first month of storage, the $\mathrm{SO}_{2}$ level that accumulated in the liners was usually below 8 ppm, whereas that in the MP was higher than $8 \mathrm{ppm}$ (the measurements began after $8 \mathrm{~d}$ of storage). In boxes with liners, the Osku and Fresca pads generated levels between 3 and 5 ppm during the first 3 weeks of storage, after which the levels decreased gradually to $2 \mathrm{ppm}$ after 7 weeks (Fig. 4A). With the Osku pads, levels reached $0 \mathrm{ppm}$ at $82 \mathrm{~d}$, when the other pads still maintained $0.8 \mathrm{ppm}$ of $\mathrm{SO}_{2}$. The Matesa pads gave higher levels of $\mathrm{SO}_{2}$ in the liners: $6 \mathrm{ppm}$ after a week of storage, rising to 9 ppm after 2 weeks and then declining. In the MP format, the Fresca pads generated the highest initial levels of $\mathrm{SO}_{2}$ with a peak of 19 ppm after 2 weeks of storage (Fig. 4B). After 1 month of storage, the $\mathrm{SO}_{2}$ levels with the Fresca pads declined to levels similar to those with the other two pads. The $\mathrm{SO}_{2}$ levels measured in all the liners were compared with the values recorded in the MP wrapping method for each time point, and the differences were significant according to the Mann-Whitney two-tailed nonparametric test until 50 $\mathrm{d}$ in storage with probability values ranging between 0.0008 and 0.0047 .

The quality of 'Zainy' grapes was determined after $33 \mathrm{~d}$ of cold storage and $3 \mathrm{~d}$ at $20^{\circ} \mathrm{C}$ (Table 6$)$. The results show that the quality of the rachis after storage was better in the MP packaging than in the liners. In only one case, the desiccation values were equal in the parallel treatments (rachis desiccation at shelf life with the Osku pad). Decay was low in both types of packages, but the average percentage of healthy bunches in the MP format was $94 \%$ compared with $78 \%$ in the liner format.

Integrating the areas under the $\mathrm{SO}_{2}$ concentration curves of the three different DR pads in the two types of packaging (Fig. 4) shows that, overall, the DR pads in the MP maintained $\mathrm{SO}_{2}$ levels between 549 and $377 \mathrm{ppm}$ during the period of storage, whereas in the liners, the amount of $\mathrm{SO}_{2}$ was between 267 and $162 \mathrm{ppm}$, not including $\mathrm{SO}_{2}$ released between days 0 and 6. This indicates $\mathrm{SO}_{2}$ levels of 5.8 and $2.6 \mathrm{ppm}$ per day in storage for the MP and the liners, respectively. Although it has been thought that a level of $7 \mathrm{ppm} \mathrm{SO}_{2}$ is necessary to prevent $B$. cinerea development in storage (Laszlo et al., 1981), the present findings indicate that lower levels may be effective. This conclusion does not account for the effect of the fast-release phase, which, as shown for the Vinguard LM pad, made a very significant impact in the control of decay. A trial of fumigation

Table 6. Comparison of quality of 'Zainy' grapes stored in boxes with liners or in boxes wrapped on the other side and with sulfur dioxide $\left(\mathrm{SO}_{2}\right)$ generator pads from three different companies. ${ }^{\mathrm{z}}$

\begin{tabular}{|c|c|c|c|c|c|}
\hline \multirow[b]{2}{*}{ Treatment $^{\mathrm{y}}$} & \multicolumn{2}{|c|}{$\begin{array}{l}\text { Rachis desiccation } \\
\qquad(1-5 \text { scale })^{x}\end{array}$} & \multicolumn{2}{|c|}{$\begin{array}{c}\text { Pedicel desiccation } \\
(1-5 \text { scale })^{x}\end{array}$} & \multirow{2}{*}{$\begin{array}{l}\text { Healthy bunches } \\
(\%)\end{array}$} \\
\hline & Storage ${ }^{\mathrm{w}}$ & Shelf life $^{\mathrm{w}}$ & Storage & Shelf life & \\
\hline F-Liner & $1.9 \pm 0.1 \mathrm{ab}^{\mathrm{v}}$ & $2.7 \pm 0.0$ & $2.3 \pm 0.4$ & $3.6 \pm 0.1 \mathrm{a}$ & $83.4 \pm 10.5 b$ \\
\hline M-Liner & $2.0 \pm 0.0 \mathrm{a}$ & $2.6 \pm 0.0$ & $2.5 \pm 0.3$ & $3.0 \pm 0.1 \mathrm{~b}$ & $83.4 \pm 12.5 b$ \\
\hline O-Liner & $2.1 \pm 0.1 \mathrm{a}$ & $2.7 \pm 0.2$ & $2.6 \pm 0.1$ & $3.4 \pm 0.1 \mathrm{ab}$ & $66.7 \pm 13.5 c$ \\
\hline F-MP & $1.7 \pm 0.1 b$ & $2.5 \pm 0.1$ & $1.8 \pm 0.1$ & $2.5 \pm 0.2 b$ & $88.9 \pm 9.6 \mathrm{ab}$ \\
\hline M-MP & $1.7 \pm 0.1 b$ & $2.5 \pm 0.0$ & $1.8 \pm 0.2$ & $2.6 \pm 0.1 b$ & $100.0 \pm 0.0 \mathrm{a}$ \\
\hline $\mathrm{O}-\mathrm{MP}$ & $1.8 \pm 0.1 b$ & $2.7 \pm 0.2$ & $2.1 \pm 0.4$ & $3.3 \pm 0.6 \mathrm{ab}$ & $94.4 \pm 9.6 \mathrm{ab}$ \\
\hline
\end{tabular}

$\overline{{ }^{z} \text { Storage was for } 33 \mathrm{~d} \text { at } 0{ }^{\circ} \mathrm{C}\left(32.0^{\circ} \mathrm{F}\right) \text { and } 3 \mathrm{~d} \text { at } 20^{\circ} \mathrm{C}\left(68.0^{\circ} \mathrm{F}\right) \text {. Quality measurements included rachis and }}$ pedicel desiccation and the percentage of bunches with one or no decayed berries at the end of storage and the $3 \mathrm{~d}$ of shelf life.

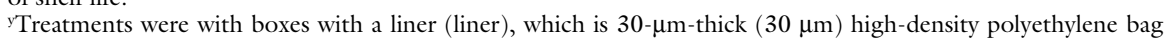
having $0.2 \%$ ventilation [holes 6 - $\mathrm{mm}(0.24 \mathrm{inch})$ diameter spaced every $12 \mathrm{~cm}(4.7$ inches $)$ ] placed inside each box or with a mini-pallet (MP; a unit of three stacked plastic boxes containing grapes wrapped around the top and sides with $30-\mu \mathrm{m}$ film of linear low density polyethylene). In each type of box, there was a dual-release (DR) $\mathrm{SO}_{2}$ generator pad from one of three manufacturers: Fresca [F (Quimetal Industries, Santiago, Chile)], Matesa [M (Empack, Santiago, Chile)], or Osku [O (Osku, Santiago, Chile)].

${ }^{\mathrm{x}} \mathrm{I}=$ rachis and pedicels full and green as at harvest; $2=$ slight browning; $3=$ browning of rachis and pedicels but no shriveling; 4 = browning and some shriveling; 5 = both rachis and pedicels dry and brown. A rating greater than 3 was considered unmarketable.

${ }^{\text {w }}$ Storage was for $33 \mathrm{~d}$ at $0{ }^{\circ} \mathrm{C}$ and shelf life was $3 \mathrm{~d}$ at $20^{\circ} \mathrm{C}$.

values in columns followed by different letters indicate significant differences according to analysis of variance with the Student-Newman-Keuls test at $P<0.05$. at a lower $\mathrm{SO}_{2}$ concentration of 600 ppm (200 ppm three times per week) rather than the commercial method of $2500 \mathrm{ppm}$ once per week led to lower levels of decay development in inoculated berries after 10 weeks at $0{ }^{\circ} \mathrm{C}$ (Marois et al., 1986). In another study, individual berries were inoculated with $B$. cinerea and then exposed to a flow-through fumigation system to simulate $\mathrm{SO}_{2}$ release from the slow-release part of a DR pad (Palou et al., 2002). Both 2 and 3 ppm $\mathrm{SO}_{2}$ effectively controlled nesting (the spread of decay to healthy berries), although it did not kill the inoculated pathogen. For this, a high level of $\mathrm{SO}_{2}$ was required at the beginning of storage (Smilanick et al., 1990). For example, a $\mathrm{SO}_{2}$ dosage that killed $99 \%$ of spores was 30 min fumigation with $200 \mathrm{ppm}$ of $\mathrm{SO}_{2}$ (Smilanick and Henson, 1992). In another study, it was found that decay did not occur in inoculated berries if they were treated with 13 ppm $\mathrm{SO}_{2}$ for $40 \mathrm{~h}$ or with $55 \mathrm{ppm}$ for $15 \mathrm{~h}$ (Zutkhi et al., 2001). It is difficult to convert the values used for fumigation to what should be released from a $\mathrm{SO}_{2}$-generating pad, because in the former case, the grapes are exposed to $\mathrm{SO}_{2}$ for only a short time and then the $\mathrm{SO}_{2}$ is removed. In the case of the $\mathrm{SO}_{2}$-releasing pads, the grapes are exposed continuously to the $\mathrm{SO}_{2}$, increasing the possibility of cumulative damage to the appearance and the taste of the berries.

The quality of the grapes in the present trials with plastic boxes was either similar with both packaging methods or better with the MP than the liner method. In general, the pedicels (and sometimes the rachis) showed more desiccation in the liners than in the MP (Tables 2, 4, and 6). The percentage of healthy bunches was also greater in the MP than in the liner storage. Desiccation is rated as drying and browning of the rachis and pedicels, which is greatly affected by the humidity around the grapes. Crisosto et al. (1994) found that water loss during postharvest operations can contribute to rachis browning. They found that rachis browning was observed on 'Thompson Seedless' grapes when water loss reached $3 \%$. Packing the grapes in containers with an unperforated liner reduced this water loss and prevented rachis 
browning during a 10-d shipping period. The same principle applies to the MP format compared with the liners, although the results cannot be directly compared, because in our present trials, a perforated liner was used and the storage was for a longer period.

\section{Conclusion}

Although the major method of grape packaging for long-distance shipment worldwide is that of perforated liners, the present study has shown that a packaging method that uses external wrapping of pallets with LLDPE can be as effective as the liner method in preventing grape decay and desiccation. Wrapping is the method of choice for exporting table grapes from Israel, but no extensive comparison of the two methods has been published previously. This method of external wrapping also has the advantage of faster precooling, because there is no barrier such as that presented by a liner. In addition, the use of less packaging material makes external wrapping more economical than the use of an individual liner for each box. The pallet-wrapping method is best when used with recyclable plastic boxes rather than cardboard ones, because there is no $\mathrm{SO}_{2}$ absorption by the plastic and appreciable absorption by the cardboard. Reusable plastic boxes may also be environmentally better than the cardboard boxes.

\section{Literature cited}

Association of Official Analytical Chemists International. 2005. Sulfites in
foods-Optimized Monier-Williams. Method 990.28. 18th ed. AOAC International, Gaithersburg, MD.

Ben-Arie, R., A. Haas, Z. Shoshani, E. Bar-Lev, M. Zeidman, and Y. Zutkhi. 1984. The effect of pre-cooling 'Perlette' table grapes wrapped in various plastic films on their keeping quality during air or sea export. HaSadeh 64:1380-1387 (in Hebrew).

Crisosto, C.H., J.L. Smilanick, N.K. Dokoozlian, and D.A. Luvisi. 1994. Maintaining table grape post-harvest quality for long distant markets. Int. Symp. Table Grape Production Soc. Enol. Viticult. 1:195-199.

Harvey, J.M., C.M. Harris, T.A. Hanke, and P.L. Hartsell. 1988. Sulfur dioxide fumigation of table grapes: Relative sorption of $\mathrm{SO}_{2}$ by fruit and packages, $\mathrm{SO}_{2}$ residues, decay and bleaching. Amer. J. Enol. Viticult. 39:132-136.

Laszlo, J., J.C. Combrink, G.J. Eksteen, and A.B. Truter. 1981. Effect of temperature on the emission of sulphur dioxide from gas generators for grapes. Deciduous Fruit Grower 31:112-119.

Lichter, A., F.M. Gabler, and J.L. Smilanick. 2006. Control of spoilage in table grapes. 5 Aug. 2007. <http://www.stewart postharvest.com/December_2006/ Lichter.pdf>.

Lichter, A., Y. Zutahy, T. Kaplunov, N. Aharoni, and S. Lurie. 2005. The effect of ethanol dip and modified atmosphere on prevention of botrytis rot of table grapes. HortTechnology 15:284291.

Marois, J.J., A.M. Bledsoe, W.D. Gubler, and D.A. Luvisi. 1986. Control of Botrytis cinerea on grape berries during postharvest storage with reduced levels of sulfur dioxide. Plant Dis. 70:10501052 .
Nelson, K.E., 1985. Harvesting and handling California table grapes for market. Univ. Calif. Div. Agr. Natural Resources, Bul. 1913.

Nelson, K.E. and M. Ahmedullah. 1976. Packaging and decay control system for storage and transit of table grapes for export. Amer. J. Enol. Viticult. 24:74-79.

Palou, L., C.H. Crisosto, D. Garner, L.M. Basinal, J.L. Smilanick, and J.P. Zoffoli. 2002. Minimum constant sulfur dioxide emission rates to control gray mold of cold-stored table grapes. Amer. J. Enol. Viticult. 53:110-115.

Peiser, G.D. and S.F. Yang. 1985. Metabolism of sulfur dioxide in 'Thompson Seedless' grape berries. J. Amer. Soc. Hort. Sci. 110:224-226.

Peynaud, E. and P. Ribereau-Gayon. 1971. The grape, p. 172-206. In: A.C. Hulme (ed.). The biochemistry of fruits and their products. Academic Press, New York.

Smilanick, J.L., P.I. Hartsell, D.J. Henson, D.C. Fouse, M. Assemi, and C.M. Harris. 1990. Inhibitory activity of sulfur dioxide on the germination of spores of Botrytis cinerea. Phytopathology 80:217-220.

Smilanick, J.L. and D.J. Henson. 1992. Minimum gaseous sulphur dioxide concentrations and exposure periods to control Botrytis cinerea. Crop Prot. 11:535-540.

U.S. Government Printing Office. 1986. Interim policy for sulfating agents on grapes. Fed. Regist. 51:47240-47241.

Winkler, A.J. and H.E. Jacob. 1925. The utilization of sulphur dioxide in the marketing of grapes. Hilgardia 1:107-131.

Zutkhi, Y., T. Kaplunov, A. Lichter, R. Ben Arie, S. Lurie, I. Kosto, and E. Raban. 2001. Extended storage of Redglobe grapes. Acta Hort. 553:617-618. 